\title{
Development of a Potent Antimicrobial Peptide With Photodynamic Activity
}

\author{
Di Zhang ${ }^{1 t}$, Jingyi Chen ${ }^{1 \dagger}$, Qian Jing ${ }^{1 \dagger}$, Zheng Chen ${ }^{1}$, Azeem Ullah ${ }^{1}$, Longguang Jiang ${ }^{1}$, \\ Ke Zheng ${ }^{1}$, Cai Yuan ${ }^{2 *}$ and Mingdong Huang ${ }^{1 *}$ \\ ${ }^{1}$ College of Chemistry, Fuzhou University, Fuzhou, China, ${ }^{2}$ College of Biological Science and Engineering, Fuzhou University, \\ Fuzhou, China
}

OPEN ACCESS

Edited by:

Jack Wong,

Caritas Institute of Higher Education,

China

Reviewed by:

Kaushiki Mazudar,

Kelly Government Solutions,

United States

Angela Cunha,

University of Aveiro, Portugal

Grzegorz Szewczyk,

Jagiellonian University, Poland

*Correspondence:

Cai Yuan

cyuan@fzu.edu.cn

Mingdong Huang

HMD_lab@fzu.edu.cn

tThese authors have contributed equally to this work

Specialty section:

This article was submitted to Antimicrobials, Resistance and

Chemotherapy,

a section of the journal

Frontiers in Microbiology

Received: 31 October 2020 Accepted: 08 April 2021

Published: 01 June 2021

Citation:

Zhang D, Chen J, Jing Q, Chen Z,

Ullah A, Jiang L, Zheng $K$,

Yuan $C$ and Huang M (2021)

Development of a Potent

Antimicrobial Peptide With

Photodynamic Activity.

Front. Microbiol. 12:624465.

doi: 10.3389/fmicb.2021.624465
The emergence of antibiotic-resistant bacteria poses a serious challenge to medical practice worldwide. A small peptide with sequence RWRWRW was previously identified as a core antimicrobial peptide with limited antimicrobial spectrum to bacteria, especially Gram-positive bacteria. By conjugating this peptide and its analogs with lipophilic phthalocyanine (Pc), we identified a new antibiotic peptide $\left[\mathrm{PcG}_{3} \mathrm{~K}_{5}(\mathrm{RW})_{3}\right]$. The peptide demonstrates increased antimicrobial effect to both Gram-positive Staphylococcus aureus and Gram-negative Escherichia coli. In addition, Pc also provides added and potent antimicrobial effect upon red light illumination. The inhibitory efficacy of $P_{c} G_{3} K_{5}(R W)_{3}$ was increased by $\sim 140$-fold to nanomolar range upon illumination. Moreover, $P_{c} G_{3} K_{5}(R W)_{3}$ was safe for mammalian cell and promoted wound healing in the mouse infection model. Our work provides a new direction to optimize antimicrobial peptides to enhance antimicrobial efficacy.

Keywords: antimicrobial peptide, Gram-negative bacteria, phthalocyanine, hydrophobicity, antibiotic resistance

\section{INTRODUCTION}

During the past few decades, antimicrobial resistance (AMR) of bacteria has become a worldwide threat to public health. The WHO has recently issued a priority list of pathogen strains that have acquired resistance to most, and in some cases to all, antibiotics at a global level and advocates urgent needs to develop treatment for these AMR strains for human health (Tacconelli et al., 2018). The list includes both Gram-negative and Gram-positive bacterial strains. Gramnegative bacteria, with an outer membrane to protect themselves from unwanted compounds, are difficult to inhibit by traditional antibiotics (Payne et al., 2007; Lewis, 2013). Daptomycin is a lipopeptide antibiotic approved by the US Food and Drug Administration (FDA) in 2003 to treat infection induced by Gram-positive bacteria (Sauermann et al., 2008). Daptomycin contains amphiphilic 13mer peptide and a decanoyl fatty acid tail. Darobactin is a recently reported peptide antibiotic (Imai et al., 2019) with low toxicity and strong potency against AMR Gram-negative pathogens. Broad-spectrum antibiotics with inhibitory activities to both Gram-positive and Gram-negative strains have strong advantages and are much needed.

Antimicrobial peptides (AMPs) have multiple targets on pathogenic microbes, including the cytoplasmic membrane and cell division and synthesis of essential proteins (Okorochenkov et al., 2012). One drawback of AMPs is their limited antimicrobial spectrum, susceptibility toward proteolytic degradation, and moderate antimicrobial activity (Habets and Brockhurst, 2012; 
Niu et al., 2013). In addition, the strategy for AMP optimization is generally not well defined, except the development of various formulation methods (Mahlapuu et al., 2016), including nanocarriers. Arginine- and tryptophan-rich peptides are a class of promising lead structures with inhibitory effect against Grampositive bacterial strains but less activity against Gram-negative bacteria (Strom et al., 2002, 2003; Choi and Moon, 2009; Dennison et al., 2009; Albada et al., 2012; Arias et al., 2014; Wenzel et al., 2014, 2016a,b). The presence of lipophilic groups in AMPs appears to be important for high potency, as demonstrated by two successful examples. Daptomycin is a 13 mer lipopeptide antibiotic containing decanoyl fatty acid tail and was approved by the US FDA in 2003 to treat infections caused by Grampositive bacteria (Sauermann et al., 2008). Darobactin is a recently reported peptide antibiotic (Imai et al., 2019) with low toxicity and strong potency and contains three aromatic rings.

A hexapeptide RWRWRW was shown to be the shortest unit possessing effective antimicrobial efficacy (Strom et al., 2003; Liu et al., 2007; Albada et al., 2012; Wenzel et al., 2016a). The peptide showed a limited antimicrobial spectrum of only medium antimicrobial activity against Gram-positive bacteria but less activity against Gram-negative bacteria. The structure and functional studies on these arginine- and tryptophan-rich peptides clearly demonstrated the importance of strong lipophobicity (Liu et al., 2007; Albada et al., 2012; Wenzel et al., 2016a) for antimicrobial activity. For example, tyrosine was found to be less effective in providing bulk and lipophilicity than tryptophan (Strom et al., 2003). In this work, we incorporate a new lipophilic group, phthalocyanine (Pc), into the RWRWRW unit to synthesize a series of peptides and identify a potent AMP (Scheme 1). Pc not only provides hydrophobicity for bacterial membrane attachment but also becomes photocytotoxic to microbes when illuminated by red light at a specific wavelength [680 nm; Morley and Charlton, 1995; Gardberg et al., 2001; named antimicrobial photodynamic therapy (aPDT)]. No known bacterial resistance to aPDT has been reported (Chen et al., 2017; Wainwright et al., 2017). The peptide is shown to be safe to mammalian cells and has antimicrobial activity in a wound infection mouse model. Importantly, the peptide is active not only against Gram-positive Staphylococcus aureus but also against Gram-negative bacteria and even to multiresistant bacterial strains [methicillin-resistant S. aureus (MRSA)]. In addition, with the illumination of red light, the antimicrobial efficacy increased by $\sim 140$-fold against either Gram-positive or -negative bacterial strains $\left(\mathrm{IC}_{50} \mathrm{~s}\right.$ of $85 \mathrm{nM}$ against $S$. aureus and $163 \mathrm{nM}$ against Escherichia coli). We also demonstrated the antibacterial efficacy of the peptide in a mouse skin infection model. The strategy used here can be used to empower and expand the antimicrobial spectrum of other AMPs.

\section{MATERIALS AND METHODS}

\section{Materials}

The side chain-protected peptides $\mathrm{G}_{3}(\mathrm{RW})_{3}, \mathrm{G}_{3}(\mathrm{RW})_{3} \mathrm{~K}_{5}$, and $\mathrm{G}_{3} \mathrm{~K}_{5}(\mathrm{RW})_{3}$ on Wang resin were obtained commercially (GL
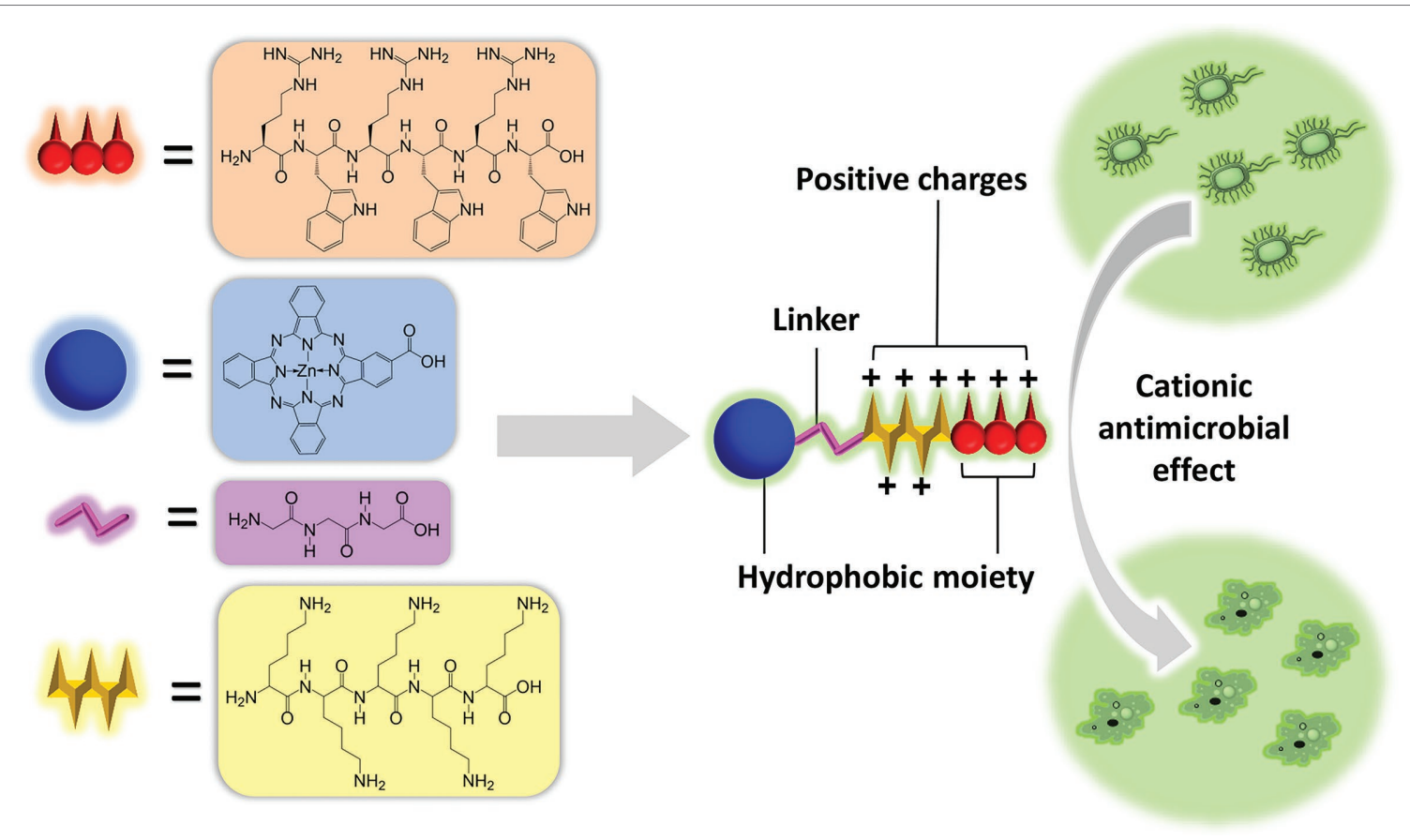

SCHEME 1 | A new antibiotic peptide $\left[\mathrm{PCG}_{3} \mathrm{~K}_{5}(\mathrm{RW})_{3}\right]$ was identified by conjugating a small peptide of sequence RWRWRW or its analogues with lipophilic phthalocyanine $(\mathrm{Pc})$. The peptide demonstrates enhanced antimicrobial effect to both Gram-positive S. aureus and Gram-negative E. coli. In addition, the inhibitory efficacy of the peptide was increased by 140-fold to nanomolar range upon LED illumination. Moreover, the peptide was safe to mammalian cell, and promoted wound healing in mice infection model. 
Biochem Ltd., Shanghai). Beta-carboxy phthalocyanine zinc was developed by us by a method previously reported (Chen et al., 2006). Beta-carboxy phthalocyanine ( $\beta$ - $\mathrm{PcCOOH})$ was purified on a silica column with $\mathrm{N}, \mathrm{N}$-dimethylformamide (DMF):acetone (3:1) as the second band. All the chemical reagents were analytical grade and used without further purification. Distilled water was used throughout the experiments. E. coli (ATCC 8739), S. aureus (ATCC 6538), and MRSA (ATCC 33591) were acquired from ATCC. Bioluminescent strains of E. coli DH5 $\alpha$ were constructed by transformation of plasmid pAKlux2.1, which contained a complete bacterial luciferase operon as described (Ullah et al., 2018; Chen et al., 2019), and S. aureus Xen29 (NCTC8532) containing a stable copy of the modified Photorhabdus luminescens luxABCDE operon was purchased from Shanghai Biofeng Company.

\section{Synthesis and Characterization}

$\beta$-PcCOOH was conjugated with side chain-protected $\mathrm{G}_{3}(\mathrm{RW})_{3}$, $\mathrm{G}_{3}(\mathrm{RW})_{3} \mathrm{~K}_{5}$, or $\mathrm{G}_{3} \mathrm{~K}_{5}(\mathrm{RW})_{3}$ on Wang resin. In a typical conjugation reaction, $\beta$-carboxy phthalocyanine zinc ( $49.76 \mathrm{mg}, 0.08 \mathrm{mmol}$ ) was dissolved in $2 \mathrm{ml} \mathrm{DMF}$. Hexafluorophosphate benzotriazole tetramethyl uronium (HBTU; $61 \mathrm{mg}, 0.16 \mathrm{mmol}$ ) and diisopropylethylamine (DIEA; $0.1 \mathrm{ml}$ ) were added to the solution and stirred for $30 \mathrm{~min}$. The Wang resin with peptide $\mathrm{G}_{3}(\mathrm{RW})_{3}$, $\mathrm{G}_{3}(\mathrm{RW})_{3} \mathrm{~K}_{5}$, or $\mathrm{G}_{3} \mathrm{~K}_{5}(\mathrm{RW})_{3}(200 \mathrm{mg}, 0.08 \mathrm{mmol})$ was added into the solution, and the mixture was stirred for $24 \mathrm{~h}$. After the reaction was completed, the filtered solid was washed three times by DMF and methanol until the filtrate became colorless. The residue was then treated with $95 \%$ trifluoroacetic acid (TFA) for $4 \mathrm{~h}$ at room temperature to remove the protecting groups and the Wang resin. The TFA-treated solution was filtered on a Buchner funnel, and the filtrate was concentrated with rotary evaporation, followed by the addition of cool anhydrous ethyl ether to obtain precipitate. The new synthetic compounds were further purified on a preparative highperformance liquid chromatography (HPLC; Dalian Elite Analytical Instruments Co. Ltd., Dalian, China) using a reverse phase column (Sino Chrom ODS-BP, $10 \mathrm{~mm}$ ), eluted with a linear gradient of $50-100 \%$ in dimethyl sulfoxide (DMSO) in $0.01 \%$ TFA in a period of $30 \mathrm{~min}$ at a flow rate of $5 \mathrm{ml} /$ min. UV-Vis spectra and photo-degraded curve was measured by BioTek Synergy 4 multi-mode microplate reader in a 96 -well plate at room temperature. The UV-Vis absorption spectrum of antimicrobial Pc-peptides (APPs) in DMSO was typical of $\mathrm{Pc}$ with the strongest absorption at $678 \mathrm{~nm}$ (extinction coefficient of $\left.118,380 \mathrm{~L} \cdot \mathrm{mol}^{-1} \cdot \mathrm{cm}^{-1}\right)$. The synthetic AMPs were further characterized by high-resolution mass spectra.

\section{Antimicrobial Activity Assays Using Bioluminescent Bacteria}

Bioluminescent bacteria were grown in Luria-Bertani (LB) culture medium at $37^{\circ} \mathrm{C}$ under aerobic conditions overnight 8-12 diluted 100 times to $10^{6}$ colony-forming units (CFU)/ $\mathrm{ml}$ in phosphate buffered saline (PBS) before incubating with the peptides. The peptide or new compounds were first dissolved in PBST (PBS with $0.05 \%$ Tween 20) to prepare 1-mM stock solutions, and the solutions were then further diluted up to $100 \mu \mathrm{M}$ with PBST. The bacterial suspensions were then incubated in 96-well plates with the compound peptides. The luminescence was monitored for $1 \mathrm{~h}$ to measure the bacterial viability. The percentage of survived bacteria was determined from the luminescence intensities of the treated group divided by the luminescence signal of the controls.

For photo-assisted antimicrobial activity measurements against bioluminescent bacteria, we used a procedure similar to as above, but with illumination using LM-LED light $(680 \mathrm{~nm})$ for $6 \mathrm{~min}$ (light dose of $12 \mathrm{~J} / \mathrm{cm}^{2}, 33.33 \mathrm{~mW} / \mathrm{cm}^{2}$ ) after $10 \mathrm{~min}$ incubation of the bacterial suspensions and the compound peptides.

\section{Antimicrobial Activity Assays Using ATCC Standard Strains}

E. coli (ATCC 8739), S. aureus (ATCC 6538), or MRSA (ATCC 33591) were grown in $\mathrm{LB}$ culture medium at $37^{\circ} \mathrm{C}$ under aerobic conditions overnight $(8-12 \mathrm{~h})$ before use.

Minimum inhibitory concentrations (MICs) were measured by the double dilution method. Inocula of bacteria were prepared by adjusting overnight cultures in LB medium. Aliquots of $100 \mu \mathrm{l}$ of the inocula were mixed with $900 \mu$ peptides of serial double dilutions in centrifuge tubes and then incubated with shaking at $37^{\circ} \mathrm{C}$ for $20 \mathrm{~h}$ without light. MICs were defined as the lowest concentrations of the peptides that completely inhibit the growth of bacteria (final concentration of $10^{6} \mathrm{CFU} / \mathrm{ml}$ ). Bactericidal kinetics assay was also determined. Different final concentrations $(0,1 / 8-, 1 / 4-, 1 / 2-, 1-\mathrm{MIC})$ of the peptides were added to the bioluminescent $S$. aureus suspension $\left(10^{3} \mathrm{CFU} / \mathrm{ml}\right)$. The bacteria were incubated at $37^{\circ} \mathrm{C}$ and $150 \mathrm{rpm}$. An aliquot of $100 \mu \mathrm{l}$ of the suspension was taken out to measure the absorption at $600 \mathrm{~nm}$ on microplate reader once an hour for up to $12 \mathrm{~h}$.

Photo-assisted antimicrobial activity assays of the compound peptides against ATCC standard strains were carried out by colony counting method. The agar plates with only bacterial suspension were used as negative control. The peptide and bacterial suspension were incubated together in 96-well microplates first. Under the same conditions, for comparison, the other groups were set without light. After incubation for $40 \mathrm{~min}$ at room temperature, aliquots of $100 \mu \mathrm{l}$ were taken out of the solutions and placed on agar plates at serial dilutions, then incubated at $37^{\circ} \mathrm{C}$ for $18-24 \mathrm{~h}$. Numbers of colonies were counted, and the antimicrobial rate $(\mathrm{R})$ was calculated: $\mathrm{R}=(\mathrm{B}-\mathrm{A}) / \mathrm{B} \times 100 \%$. Here, $\mathrm{A}$ is the bacterial colony number on the agar plates containing various concentrations of the peptides, and $\mathrm{B}$ is the colony number for negative control. A similar procedure was carried out to study the effect of low dose of light on the activity of $\mathrm{PcG}_{3} \mathrm{~K}_{5}(\mathrm{RW})_{3}$ against $S$. aureus (ATCC 6538) and E. coli (ATCC 8739), except the changing irradiate light doses $\left(0,0.15,0.3,0.45\right.$, and $\left.0.6 \mathrm{~J} / \mathrm{cm}^{2}\right)$.

\section{Reactive Oxygen Species Measurement}

The reactive oxygen species (ROS) generated by Pc mainly includes singlet oxygen and may also contain hydroxyl radical 
in some cases. In this study, the ROS generation of $\mathrm{PcG}_{3} \mathrm{~K}_{5}(\mathrm{RW})_{3}$ was measured with a probe [2,7-dichlorofluorescein diacetate (DCFH-DA)]. In the presence of ROS, 2',7'-dichlorofluorescin diacetate (DCFH-DA) can be converted to 2,7-dichlorofluorescein (DCF, ex $400 \mathrm{~nm}$, em $528 \mathrm{~nm}$ ). 1,3-Dimethyl-2-thiourea (DMT) is a quencher of hydroxyl radical, while $\mathrm{NaN}_{3}$ is a quencher for singlet oxygen. In a 96-well white plate, peptide $\mathrm{PcG}_{3} \mathrm{~K}_{5}(\mathrm{RW})_{3}$ or $\mathrm{G}_{3} \mathrm{~K}_{5}(\mathrm{RW})_{3}$ (for control) was added into the solution of DCFH-DA $(100 \mu \mathrm{M})$ with or without DMT $(1 \mathrm{M})$ and/or $\mathrm{NaN}_{3}(30 \mathrm{mM})$ to the final concentration of peptide at $10 \mu \mathrm{M}$ and the total volume of $200 \mu \mathrm{l}$ (using PBS as buffer). The solutions were illuminated using a planar LED light source for $5 \mathrm{~min}$ at intervals, and the emission intensity of DCF at $528 \mathrm{~nm}$ was measured every $30 \mathrm{~s}$ after illumination. The no-light radiation group was used as control.

\section{Scanning Electron Microscope}

The morphology changes of bacteria treated with $\mathrm{PcG}_{3} \mathrm{~K}_{5}(\mathrm{RW})_{3}$ were observed using SEM. Untreated bacteria acted as the control. E. coli strains (ATCC 8739) were harvested by centrifuging at $6,000 \mathrm{rpm}$ for $10 \mathrm{~min}$ and washed with sterile PBStwice. For the fixation, the bacteria were fixed with precooling $2.5 \%(\mathrm{v} / \mathrm{v})$ glutaraldehyde in PBS overnight at $4^{\circ} \mathrm{C}$. For dehydration, the bacteria were dehydrated by a graded series of ethanol $(30,50,70,90$, and $100 \%)$ for about $10 \mathrm{~min}$. The dehydrated E. coli solution was dropwise onto silicon wafer and dried at $37^{\circ} \mathrm{C}$ overnight. Then, prepared specimens were sprayed with gold before observation using SEM.

\section{Bacterial Membrane Permeability Assay}

Membrane permeability of bacteria was determined by the 8-aniline-1-naphthalene sulfonic acid (ANS) uptake assay. The bacteria $\left(10^{8} \mathrm{CFU} / \mathrm{ml}\right)$ were washed with $\mathrm{PBS}$ and suspended $(3,000-4,000 \mathrm{rpm})$ to $\mathrm{OD}_{600}=0.1-0.3 . \mathrm{PcG}_{3} \mathrm{~K}_{5}(\mathrm{RW})_{3}$ (final concentration of $10 \mu \mathrm{M}$ ) was added to bacterial suspension (E. coli ATCC 8739) before illumination (light dose of $12 \mathrm{~J} /$ $\mathrm{cm}^{2}, 33.33 \mathrm{~mW} / \mathrm{cm}^{2}$ ) was conducted. A group without light illumination was set up as control. The fluorescent hydrophobic probe ANS with a final concentration of $5.65 \mathrm{mM}$ was added to bacterial suspension, and fluorescence intensity was recorded. The excitation and emission wavelengths of ANS were set at 380 and $520 \mathrm{~nm}$, respectively.

\section{In vivo Antimicrobial Test in Mammal Anti-infection Model}

A localized infection mouse model was established to evaluate the antibacterial activity of $\mathrm{PcG}_{3} \mathrm{~K}_{5}(\mathrm{RW})_{3}$ against $S$. aureus in vivo according to the procedure that we previously established (Zhang et al., 2018; Chen et al., 2019). Kunming mice (4-weekold, $25 \pm 2 \mathrm{~g}$, purchased from Shanghai SLAC Laboratory Animal Co. Ltd., Shanghai, China) were maintained and handled in accordance with the recommendations of the Institutional Animal Care And Use Committee (IACUC). Mice were divided into three groups: two groups were treated with $\mathrm{PcG}_{3} \mathrm{~K}_{5}(\mathrm{RW})_{3}$ and $S$. aureus, with or without light, another group was treated with only S. aureus. Each group had six mice. All groups of mice were allowed free access to water and food throughout the experimental process. In each group, excisional wounds $(10 \mathrm{~mm} \times 10 \mathrm{~mm})$ was made on the dorsal surface of the mouse by disinfected scissors to a depth of $2.0 \mathrm{~mm}$. The bottom of the wound was panniculus carnosus with no visible bleeding. An aliquot $(50 \mu \mathrm{l})$ of mid-log phase S. aureus $\left(10^{8} \mathrm{CFU} / \mathrm{ml}\right)$ was then inoculated into each wound of mice. In the experimental group, $50 \mu \mathrm{l}$ saline solution of $\mathrm{PcG}_{3} \mathrm{~K}_{5}(\mathrm{RW})_{3}$ at final concentration of $20 \mu \mathrm{M}$ (concentration of MIC) was added into the wound surface after inoculation with S. aureus. The area of the wounds and body weight of mice were measured each day.

\section{In vivo Biosafety and Stability Measurement}

In order to evaluate the biosafety of $\mathrm{PcG}_{3} \mathrm{~K}_{5}(\mathrm{RW})_{3}$, we measured its cytotoxicity on human embryonic lung fibroblast cells. Aliquots $(100 \mu \mathrm{l})$ of cells $\left(\sim 10^{5}\right.$ per $\left.\mathrm{ml}\right)$ were incubated in 96-well plates with $\mathrm{PcG}_{3} \mathrm{~K}_{5}(\mathrm{RW})_{3}$ at various concentrations (0.8, $1.6,3.1,6.3,12.5,25,50$, and $100 \mu \mathrm{M})$ at $37^{\circ} \mathrm{C}$ for $24 \mathrm{~h}$. The culture medium was used as control. The cells were washed with PBS, then were divided into two groups, and the light group was exposed to $12 \mathrm{~J} / \mathrm{cm}^{2}$ of $680 \mathrm{~nm}$ light illumination. After another 12-h incubation, the culture medium was refreshed and 3-(4,5-dimethylthiazol-2-yl)-2,5-diphenyltetrazolium bromide (MTT) was added. After 4 -h incubation at $37^{\circ} \mathrm{C}$, the absorbance at $490 \mathrm{~nm}$ was measured on a multi-mode microplate reader (BioTek Synergy 4). The inhibition rate of cell growth was calculated by the following equation:

$$
\text { Cell viability }(\%)=\left(\begin{array}{l}
\text { Mean absorbance value of } \\
\text { treatment group }
\end{array}\right) \times 100 \%
$$

Meanwhile, an in vitro hemolysis assay was performed to evaluate hemoglobin $(\mathrm{Hb})$ release in the plasma (as an indicator of red blood cell lysis) following peptide $\mathrm{PcG}_{3} \mathrm{~K}_{5}(\mathrm{RW})_{3}$ exposure. Typically, $450 \mu \mathrm{l} 0.9 \% \mathrm{NaCl}, 450 \mu \mathrm{l} 2 \%$ red blood cells, and $100 \mu \mathrm{l} \mathrm{PcG}_{3} \mathrm{~K}_{5}(\mathrm{RW})_{3}$ (at final concentrations of $0.5,5,50$, and $500 \mu \mathrm{M})$ were mixed together and incubated in a $37^{\circ} \mathrm{C}$ for $30 \mathrm{~min}$. Positive control (containing $450 \mu \mathrm{l} 2 \%$ red blood cell only) and negative control (containing $550 \mu \mathrm{l} 0.9 \% \mathrm{NaCl}$ and $450 \mu \mathrm{l} 2 \%$ red blood cell) were designed as quality controls. Then, red blood cells were pelleted down by centrifuging the samples at $1,500 \mathrm{rpm}$ for $10 \mathrm{~min}$. The supernatant was aspirated, and the extent of hemolysis was quantified by determining the amounts of released $\mathrm{Hb}$ in the supernatant at $545 \mathrm{~nm}$ against $\mathrm{Hb}$ standard. Hemolysis rate $Z$ can be calculated by the following equation:

$$
Z(\%)=\left(\frac{D t-D n c}{D p c-D n c}\right) \times 100 \%
$$

Here, $D t, D n c$, and $D p c$ represent the absorption values at $545 \mathrm{~nm}$ of samples, the negative controls, and the positive controls.

In order to test the stability of $\mathrm{PcG}_{3} \mathrm{~K}_{5}(\mathrm{RW})_{3}$ when exposed to some proteases in human, we incubated the saline solution of $\mathrm{PcG}_{3} \mathrm{~K}_{5}(\mathrm{RW})_{3}$ (final concentration of $100 \mu \mathrm{M}$ ) with high concentration $(200 \mathrm{nM})$ of trypsin and equal volume of saline 
solution for the control group. Then, all groups were incubated at $37^{\circ} \mathrm{C}$ for $30 \mathrm{~min}$. Supernatant of centrifugation was measured in HPLC, and the procedure was the same as we mentioned above.

\section{In vivo Biodistribution and Clearance Measurement}

In order to find out metabolic characteristics of $\mathrm{PcG}_{3} \mathrm{~K}_{5}(\mathrm{RW})_{3}$ in vivo, we evaluated the biodistribution and clearance of $\mathrm{PcG}_{3} \mathrm{~K}_{5}(\mathrm{RW})_{3}$ in organs and blood of mice. Kunming mice were divided into eight groups (five mice per group), and the $\mathrm{PcG}_{3} \mathrm{~K}_{5}(\mathrm{RW})_{3}(50 \mu \mathrm{M})$, RWRWRW $(0.4 \mathrm{mg} / \mathrm{kg}$ of mouse body weight), or saline was injected through the tail vein. The mice were sacrificed at $2,4,8,12,24,36,48$, and $72 \mathrm{~h}$ post-injection, and their primary organs (liver, kidneys, heart, spleen, lung, stomach, intestines) or muscles were collected postmortem. Meanwhile, their blood was collected through enucleation of eyeballs. These samples were then washed with saline and imaged on the three-dimension FMT 2500TM LX (PerkinElmer, Waltham, MA, United States) using the same acquisition settings as the in vivo imaging to quantitate the peptide average concentrations in the samples.

The blood of mice was diluted 10 times with DMF, immediately after collection, and then centrifuged to get supernatant for further determination. The supernatant was measured by fluorescence spectrophotometer F-4600 (HITACHI, Tokyo, Japan). The fluorescence intensity was recorded. The excitation and emission wavelengths were set at 610 and $680 \mathrm{~nm}$. Then, the plasma concentrations of the $\mathrm{PcG}_{3} \mathrm{~K}_{5}(\mathrm{RW})_{3}$ were determined using a concentration-fluorescence standard curve we made. The plasma half-life $\left(t_{1 / 2}\right)$ can be calculated by the following formula:

$$
t_{1 / 2}=\frac{0.693}{(-2.303 k)}
$$

Here, $k$ represents the slope of fluorescence intensity-log (concentration) regression equation.

\section{Statistical Analysis}

Each test was repeated at least three times. The data were presented as the means \pm SD. Statistical analysis was performed using one-way analysis of variance. Multiple comparisons of the means were done by the least significant difference test. All computations were made by employing statistical software.

\section{RESULTS AND DISCUSSION}

\section{New Antimicrobial Peptides: Design, Synthesis, and Characterization}

Introduction of hydrophobic moieties, like acyl or aliphatic chains, is an optimization strategy for stronger antimicrobial efficacy and broader antimicrobial spectrum (Radzishevsky et al., 2005, 2007; Smith et al., 2018). Pc is a synthetic hydrophobic compound with aromatic ring size equivalent to four indole side chains of tryptophan. The use of Pc has an added feature: upon absorption of light at $680 \mathrm{~nm}$ (maximal absorption of the $\mathrm{Pc}), \mathrm{Pc}$ will undergo inter-system crossing and react with molecular oxygen, generating ROS that eliminates pathogens nearby (Zhang et al., 2018; Chen et al., 2019).

Here, we design a series of AMPs with Pc linked to RWRWRW hexapeptidyl unit separated by a triglycine spacer (Figure 1). The carboxyl terminal of peptides was not amidated to promote aqueous solubility after conjugating hydrophobic Pc group. Pentalysine moiety $\left(\mathrm{K}_{5}\right)$ was also integrated into the peptide chain for two purposes: (1) enhance aqueous solubility and (2) increase antimicrobial efficacy to Gram-positive strains. Polylysine is an FDA-approved food preservative used in sushi, with a dose up to $50 \mathrm{mg} / \mathrm{kg}$, and has a wide antimicrobial spectrum with good activity inhibiting Gram-negative bacteria. Here, the pentalysine was incorporated at two different orientations: either before or after RWRWRW unit. As controls, the peptides without the Pc group or pentalysine moiety $\left(K_{5}\right)$ were also generated for comparison.

To synthesize these peptides, the side chain-protected peptides were commercially acquired, followed by their covalent conjugation at amino terminal to a mono-carboxy Pc (Chen et al., 2006, 2011; Supplementary Figure S1). The compounds were purified to highly homogeneous based on C18 reverse phase column on HPLC. The order of retention times of the compounds was consistent with the hydrophilicity and polarity predicted based on their molecular structures (Figure 2A). Compounds $\mathbf{4}$ and $\mathbf{5}$ are well soluble in DMSO and aqueous solution. By comparison, compound 3 shows poor solubility in water (Figure 2B). The soluble antimicrobial Pc-peptide (APP) compounds $\mathbf{4}$ and $\mathbf{5}$ were characterized by electrospray ionization (ESI)-mass spectrometry (MS; Supplementary Figure S2). All the synthetic antimicrobial Pc-peptides (APPs) showed strong absorptions at $680 \mathrm{~nm}$ in DMSO (Figure 2C), the typical feature of Pc (Chen et al., 2006).

\section{Antimicrobial Activities of the Antimicrobial Pc-Peptides in vitro}

To evaluate the antimicrobial activity of APPs, we used bioluminescent Gram-positive S. aureus and Gram-negative E. coli, where the bioluminescent intensity [relative luminescence units (RLUs)] was proportional to the number of live bacteria. The peptides at various concentrations were incubated with the strains, and the luminescence was monitored on a microplate reader to obtain the $\mathrm{IC}_{50}$ of new peptides against these bacteria (Table 1). Compound 4 or 5 was shown to possess 2-4 times higher efficacy on both bacterial strains than compound 1 or 2 (Table 1), especially against Gram-negative E. coli, which was likely due to the extra hydrophobicity provided by the Pc group. Compound $3\left[\mathrm{PcG}_{3}(\mathrm{RW})_{3}\right]$ exhibited moderate efficacy to bacteria compared to compound $\mathbf{4}$ or $\mathbf{5}$ but with poor aqueous solubility. Compound $4\left[\mathrm{PcG}_{3} \mathrm{~K}_{5}(\mathrm{RW})_{3}\right]$ turned out to be the most effective compound against either Gram-positive S. aureus or Gram-negative E. coli with $\mathrm{IC}_{50} \mathrm{~s}$ of 12.4 and $23.9 \mu \mathrm{M}$, respectively. It is likely that both Pc moiety and tryptophan residue of compound $\mathbf{4}$ anchor directly into the phospholipid bilayer of bacterial membrane and further lead to cell death. 
To further validate the antimicrobial efficacy, we measured MIC on two bacterial strains (E. coli ATCC 8739, S. aureus ATCC 6538) and the MRSA strain (Table 2). The results verified the conclusion obtained using bioluminescent bacteria. Compounds with Pc group (compounds 3, 4, and 5) exhibited much stronger inhibitory efficacies against either E. coli or $S$. aureus than the compounds of peptides. Furthermore, MRSA strain showed similar sensitivity to the peptides as the wildtype $S$. aureus strain. It should be mentioned that the antimicrobial efficacy data here are in the same range but slightly lower than those previously reported for RWRWRW- $\mathrm{NH}_{2}$ (Strom et al., 2002, 2003; Liu et al., 2007; Albada et al., 2012).
This is likely due to the lack of C-terminal amidation of our peptides, which appears to be a key parameter for the efficacy.

In addition, the bactericidal kinetic curves (Figure 3) were recorded to test the continuous antimicrobial effect on $S$. aureus and $E$. coli bacterial strains in $12 \mathrm{~h}$ with varied concentrations (0-, 1/8-, 1/4-, 1/2-, 1-MIC) of compound 4, which exhibited the strongest activity among all the APPs. The bacteria grew the fastest in the absence of compound $\mathbf{4}$ and reached the highest plateau among this series. The bacterial growth rate decreased in proportion to the increased concentrations of compound 4. At the concentration of MIC, the bacterial proliferation completely stopped (Figure 3).

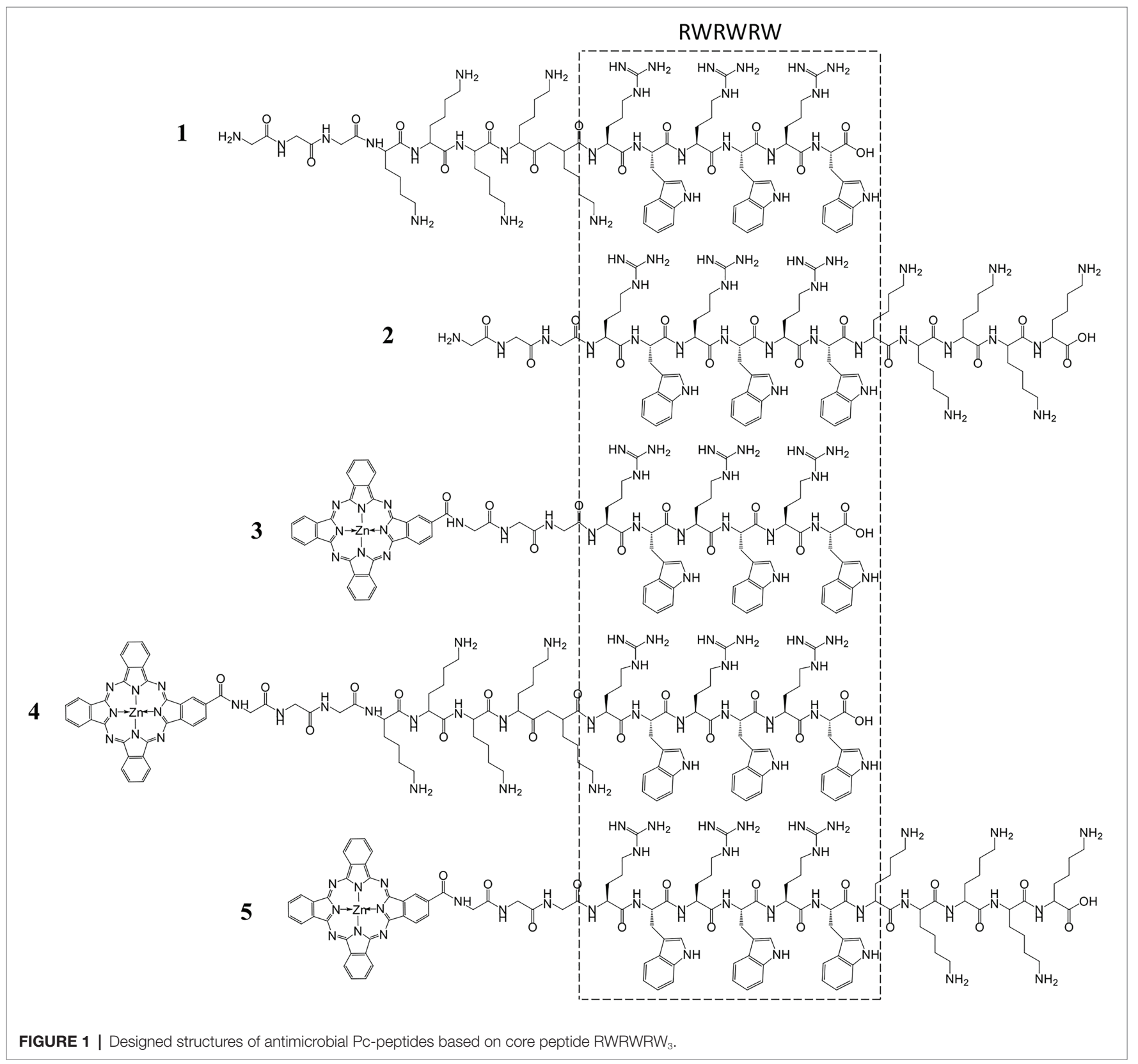




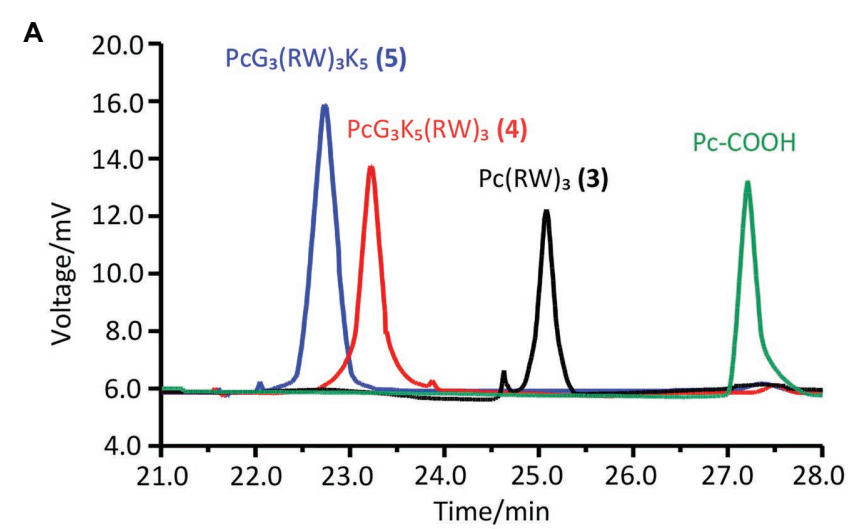

B

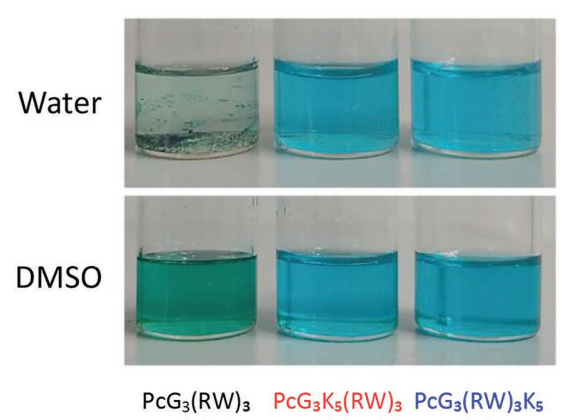

(3)

(4)

(5)

C

FIGURE 2 | Characterization of the antimicrobial Pc-peptides (APPs) and Pc-COOH. The APPs had high purity based on high-performance liquid chromatography (HPLC) profiles on C18 column (A) and different solubility in both dimethyl sulfoxide (DMSO) and water (B). All APPs exhibited a strong absorption band at 678 nm in DMSO (C).

TABLE 1 | Half-maximal inhibitory concentrations $\left(\mathrm{IC}_{50} \mathrm{~s}\right)$ of antimicrobial peptides against bacteria.

\begin{tabular}{lcc}
\hline $\begin{array}{l}\text { Compd \#, peptide } \\
\text { sequence }\end{array}$ & \multicolumn{2}{c}{$\mathbf{I C}_{50}(\mu \mathbf{M})$ against } \\
\cline { 2 - 3 } & S. aureus & E. coli \\
\hline $1, \mathrm{G}_{3} \mathrm{~K}_{5}(\mathrm{RW})_{3}$ & $45.6 \pm 2.9$ & $61.8 \pm 4.3$ \\
$2, \mathrm{G}_{3}(\mathrm{RW})_{3} \mathrm{~K}_{5}$ & $68.0 \pm 3.2$ & $135 \pm 25.3$ \\
$3, \mathrm{PcG}_{3}(\mathrm{RW})_{3}$ & $34.0 \pm 4.0$ & $73.8 \pm 1.7$ \\
$4, \mathrm{PcG}_{3} \mathrm{~K}_{5}(\mathrm{RW})_{3}$ & $12.4 \pm 0.9$ & $23.9 \pm 1.0$ \\
$5, \mathrm{PcG}_{3}(\mathrm{RW})_{3} \mathrm{~K}_{5}$ & $34.7 \pm 3.1$ & $51.2 \pm 5.5$ \\
\hline
\end{tabular}

Half-maximal inhibitory concentrations $\left(I C_{50} s\right)$ of antimicrobial peptides against Gram-positive strain S. aureus or Gram-negative strain E. coli. Each experiment was performed in triplicate.

\section{Photo-Assisted Toxicity of the Antimicrobial Pc-Peptides in vitro}

The large aromatic ring Pc also serves as a photosensitizer, generating singlet oxygen when illuminated with a $680-\mathrm{nm}$ light, leading to an additional level of toxicity to bacteria (AliAdib et al., 1998; Wrobel and Dudkowiak, 2006; Bian and Jiang, 2016). We used a LED light source that provides a stable and uniform light with the maximal intensity around $680 \mathrm{~nm}$ without heating the sample (Figure 4A). We measured the $\mathrm{IC}_{50}$ of compounds $\mathbf{4}$ and $\mathbf{5}$ on bioluminescent bacteria at a light dose of $12 \mathrm{~J} / \mathrm{cm}^{2}$ (Figure $4 \mathrm{~B}$ ). The photo-assisted
TABLE 2 | Minimum inhibitory concentrations (MICs) of antimicrobial peptides against different types of bacterial strains.

\begin{tabular}{lcccc}
\hline \multirow{2}{*}{$\begin{array}{l}\text { Compd \#, } \\
\text { peptide }\end{array}$} & $\begin{array}{c}\text { Molecular } \\
\text { sequence }\end{array}$ & mass & \multicolumn{3}{c}{ MIC $(\mu \mathbf{M})$ against } \\
\cline { 3 - 5 } & & S. aureus & MRSA & E. coli \\
\hline $1, \mathrm{G}_{3} \mathrm{~K}_{5}(\mathrm{RW})_{3}$ & $1,855.1$ & 107.8 & 107.8 & $>215.6$ \\
$2, \mathrm{G}_{3}(\mathrm{RW})_{3} \mathrm{~K}_{5}$ & $1,855.1$ & 107.8 & 107.8 & $>215.6$ \\
$3, \mathrm{PcG}_{3}(\mathrm{RW})_{3}$ & $1,676.7$ & 12.0 & 24.0 & 48.0 \\
$4, \mathrm{PcG}_{3}(\mathrm{RW})_{3} \mathrm{~K}_{5}$ & $2,488.2$ & 8.0 & 16.1 & 16.1 \\
$5, \mathrm{PcG}_{3} \mathrm{~K}_{5}(\mathrm{RW})_{3}$ & $2,488.2$ & 16.1 & 16.1 & 16.1 \\
\hline
\end{tabular}

Each experiment was performed in triplicate.

antimicrobial toxicity of this series of compounds had an overall trend similar to the toxicity without light illumination (Tables 1 and 3). Compound 4 was found to have a strong antimicrobial efficacy, with $\mathrm{IC}_{50}$ s of 85 and $163 \mathrm{nM}$ toward S. aureus and E. coli, respectively. We also measured the photo-assisted antimicrobial efficacy by colony counting method using ATCC standard strains at a starting concentration of $10^{6} \mathrm{CFU} / \mathrm{ml}$ (Figure 4C). The results showed that compound 4 induced up to $5-\log$ (i.e., 99.999\%) reduction of $S$. aureus (including antibiotic-resistant strain MRSA) and 3-log (i.e., 99.9\%) reduction of $E$. coli at a low concentration $(2 \mu \mathrm{M})$ with 6 min illumination (light dose of $12 \mathrm{~J} / \mathrm{cm}^{2}, 33.33 \mathrm{~mW} / \mathrm{cm}^{2}$; Figure $4 \mathrm{D}$ ). We also 
A

\section{E. coli}

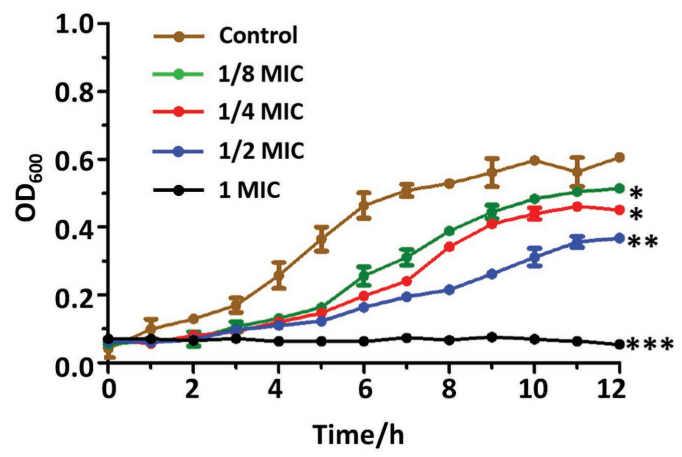

B

\section{S. aureus}

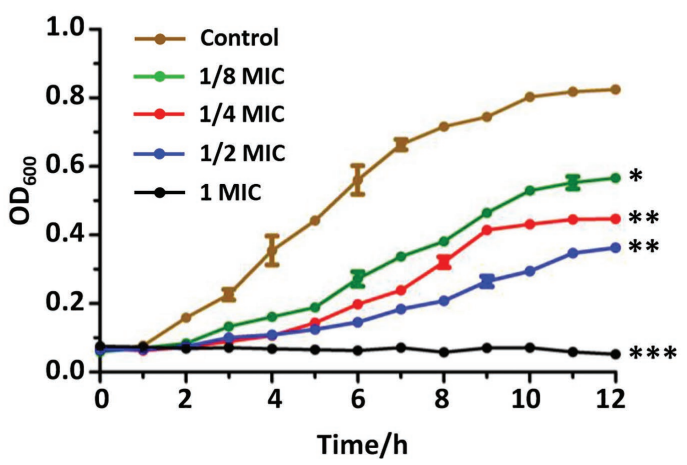

FIGURE 3 | Bactericidal kinetics of $\mathrm{PcG}_{3} \mathrm{~K}_{5}(\mathrm{RW})_{3}$. The bacterial growth of Escherichia coli $\mathbf{( A )}$ and Staphylococcus aureus (B) were slowed down in the presence of different concentrations at the concentration of $\mathrm{PcG}_{3} \mathrm{~K}_{5}(\mathrm{RW})_{3}$ at $1 / 8,1 / 4,1 / 2,1$-fold of minimum inhibitory concentration (MIC). Each experiment was performed in triplicate. ${ }^{*},{ }^{* \star}$, and ${ }^{* \star *}$ indicate significant differences $(p<0.05, p<0.01$, and $p<0.001)$ from the corresponding control group.
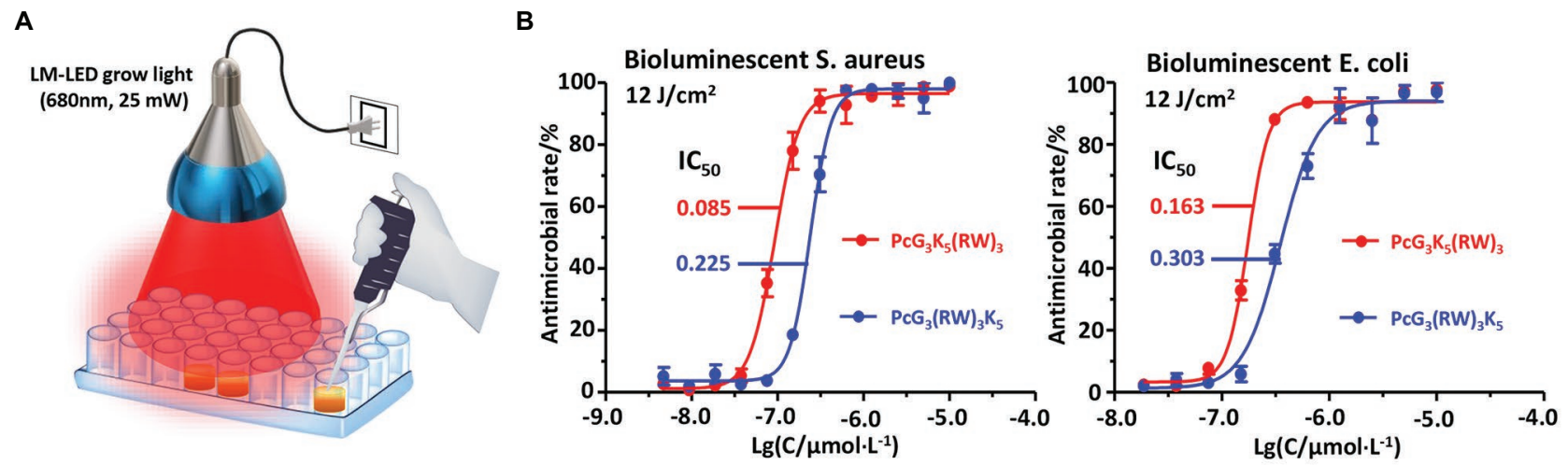

C

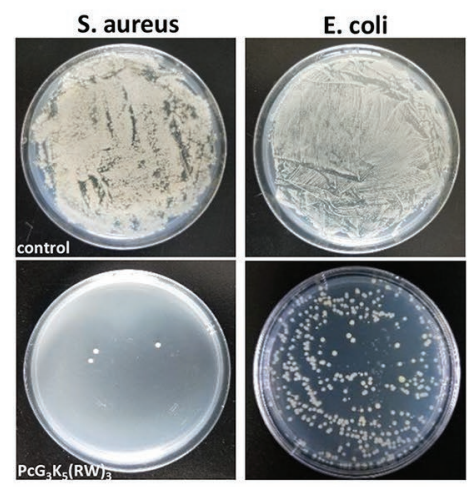

D

E
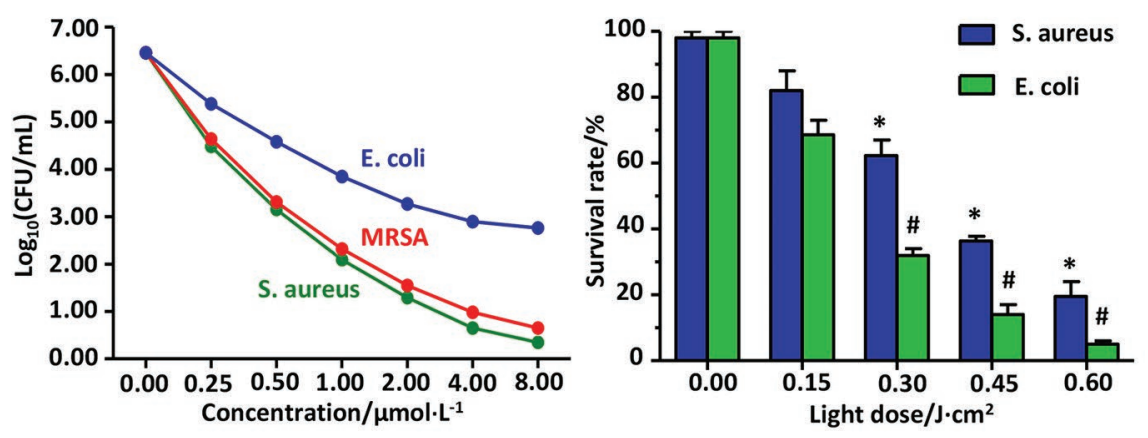

FIGURE 4 | The antimicrobial activity of $\mathrm{PcG}_{3} \mathrm{~K}_{5}(\mathrm{RW})_{3}(4)$ in the presence of light. The efficacy was measured in 96-well microplates under illumination by LM-LED (A). $P_{c} G_{3} K_{5}(R W)_{3}$ showed higher antimicrobial activity against both bioluminescent $S$. aureus and bioluminescent $E$. coli under illumination (light dose of $12 \mathrm{~J} / \mathrm{cm}^{2}$, $\left.33.33 \mathrm{~mW} / \mathrm{cm}^{2}\right)$ at a low concentration $(2 \mu \mathrm{M})$ compared to $\mathrm{PcG}_{3}(\mathrm{RW})_{3} \mathrm{~K}_{5}$ (B). $\mathrm{PcG}_{3} \mathrm{~K}_{5}(\mathrm{RW})_{3}$ induced up to 5-log reduction of $S$. aureus and 3-log reduction of $E$. coli under illumination (light dose of $12 \mathrm{~J} / \mathrm{cm}^{2}, 33.33 \mathrm{~mW} / \mathrm{cm}^{2}$ ) at a low concentration $(2 \mu \mathrm{M})$, which were measured by colony counting method (C). This peptide also showed similar activity against multiple resistant strains [methicillin-resistant $S$. aureus (MRSA)] (D). The result of short illumination indicated that the high light dose was not essential to trigger bacterial cell death (E). Error bars indicated SD for three replications. * and \# indicate significant differences to the controls of $S$. aureus (light dose $=0$ ) and $E$. coli (light dose $=0$ ), respectively $(p<0.05)$.

studied the effect of light dose for $\mathrm{PcG}_{3} \mathrm{~K}_{5}(\mathrm{RW})_{3}$ and found even a low dose of light (36-s exposure or $0.60 \mathrm{~J} / \mathrm{cm}^{2}$,
$33.33 \mathrm{~mW} / \mathrm{cm}^{2}$ ) led to the elimination of about $80 \%$ of E. coli or $95 \%$ of $S$. aureus at the concentration of $2 \mu \mathrm{M}$ (Figure $4 \mathrm{E}$ ). 


\section{Action Mechanisms of $\mathrm{PcG}_{3} \mathrm{~K}_{5}(\mathrm{RW})_{3}$}

The classic antimicrobial mechanism of AMPs is through disruption of the membrane. We studied the changes of bacterial membrane permeability after treatments by ANS, a probe for membrane permeability (Joshi et al., 1988; Liu et al., 2018). Once the probe enters the bacterial phospholipid bilayer membrane, its fluorescence intensity will increase (Misra et al., 2015). This reflects the accumulation of the probe in the lipid bilayer presumably due to the damage of cell wall, allowing more probe penetrating through cell wall and entering bacterial membrane. We observed that our peptide greatly enhanced the ANS fluorescence intensity (Supplementary Figure S3), demonstrating the increased membrane permeability. We also used SEM to study the surface morphology of $E$. coli after incubation with $\mathrm{PcG}_{3} \mathrm{~K}_{5}(\mathrm{RW})_{3}$ with or without illumination of $680 \mathrm{~nm}$. The results showed

TABLE $3 \mid I_{50}$ S of antimicrobial PC-peptides upon illumination $\left(12 \mathrm{~J} / \mathrm{cm}^{2}\right.$, $\left.33.33 \mathrm{~mW} / \mathrm{cm}^{2}\right)$.

\begin{tabular}{lcc}
\hline $\begin{array}{l}\text { Compd \#, peptide } \\
\text { sequence }\end{array}$ & \multicolumn{2}{c}{$\mathbf{I C}_{50}(\boldsymbol{\mu} \mathbf{M})$ against } \\
\cline { 2 - 3 } & S. aureus & E. coli \\
\hline $1, \mathrm{G}_{3} \mathrm{~K}_{5}(\mathrm{RW})_{3}$ & $44.640 \pm 4.720$ & $59.240 \pm 1.970$ \\
$2, \mathrm{G}_{3}(\mathrm{RW})_{3} \mathrm{~K}_{5}$ & $71.580 \pm 2.820$ & $129.230 \pm 30.340$ \\
$3, \mathrm{PcG}_{3}(\mathrm{RW})_{3}$ & $0.108 \pm 0.029$ & $0.252 \pm 0.014$ \\
$4, \mathrm{PcG}_{3} \mathrm{~K}_{5}(\mathrm{RW})_{3}$ & $0.085 \pm 0.020$ & $0.163 \pm 0.018$ \\
$5, \mathrm{PcG}_{3}(\mathrm{RW})_{3} \mathrm{~K}_{5}$ & $0.225 \pm 0.056$ & $0.303 \pm 0.036$ \\
\hline
\end{tabular}

Half-maximal inhibitory concentrations $\left(I C_{50} S\right)$ of antimicrobial peptides against Grampositive strain S. aureus or Gram-negative strain E. coli when exposed to LED light (25 mW) for $6 \mathrm{~min}$. Antimicrobial activity of Pc-peptides was further enhanced. Each experiment was performed in triplicate. that $E$. coli, a bacterium in a rod-like shape with a smooth surface (Figure 5A), presents little changes upon illumination (Figure 5B), while $\mathrm{PcG}_{3} \mathrm{~K}_{5}(\mathrm{RW})_{3}$ induced morphological damage to $E$. coli (Figure 5C), a bacterium that was typically in a rod-like shape with a smooth surface but became wrinkled and twisted in the presence of $\mathrm{PcG}_{3} \mathrm{~K}_{5}(\mathrm{RW})_{3}$. The damage was further exacerbated with light illumination (Figure 5D), leading to the outflow of cellular contents and complete fragmentation of the bacterial envelop.

Next, we studied the generation of ROS produced by $\mathrm{PcG}_{3} \mathrm{~K}_{5}(\mathrm{RW})_{3}$ with $5 \mathrm{~min}$ illumination of red light (Supplementary Figure S4; Wainwright et al., 2017; Zhang et al., 2017). We observed the steady increase of fluorescence signals of ROS probe DCFH-DA with time, indicating the production of ROS. Two types of ROS are typically produced by Pc under light illumination: either Type I (free radical) or Type II (singlet oxygen ${ }^{1} \mathrm{O}_{2}$ ), which can be quenched by either DMT or $\mathrm{NaN}_{3}$, respectively. We observed that the fluorescence of $\mathrm{PcG}_{3} \mathrm{~K}_{5}(\mathrm{RW})_{3}$ was quenched to varying degrees in the presence of DMT or $\mathrm{NaN}_{3}$ and reached the lowest in the presence of both quenchers. This indicated that $\mathrm{PcG}_{3} \mathrm{~K}_{5}(\mathrm{RW})_{3}$ generates both types of ROS upon illumination.

\section{Antimicrobial Activity of $\mathrm{PcG}_{3} \mathrm{~K}_{5}(\mathrm{RW})_{3}$ in vivo}

$S$. aureus is one of the leading causes of wound infection in hospitals and in the community and causes skin or soft tissue infections, which retard wound healing and may further lead to serious complications. A localized anti-infection model was established to evaluate the antibacterial activity of $\mathrm{PcG}_{3} \mathrm{~K}_{5}(\mathrm{RW})_{3}$ against $S$. aureus in vivo (Figure 6A). The wounds without
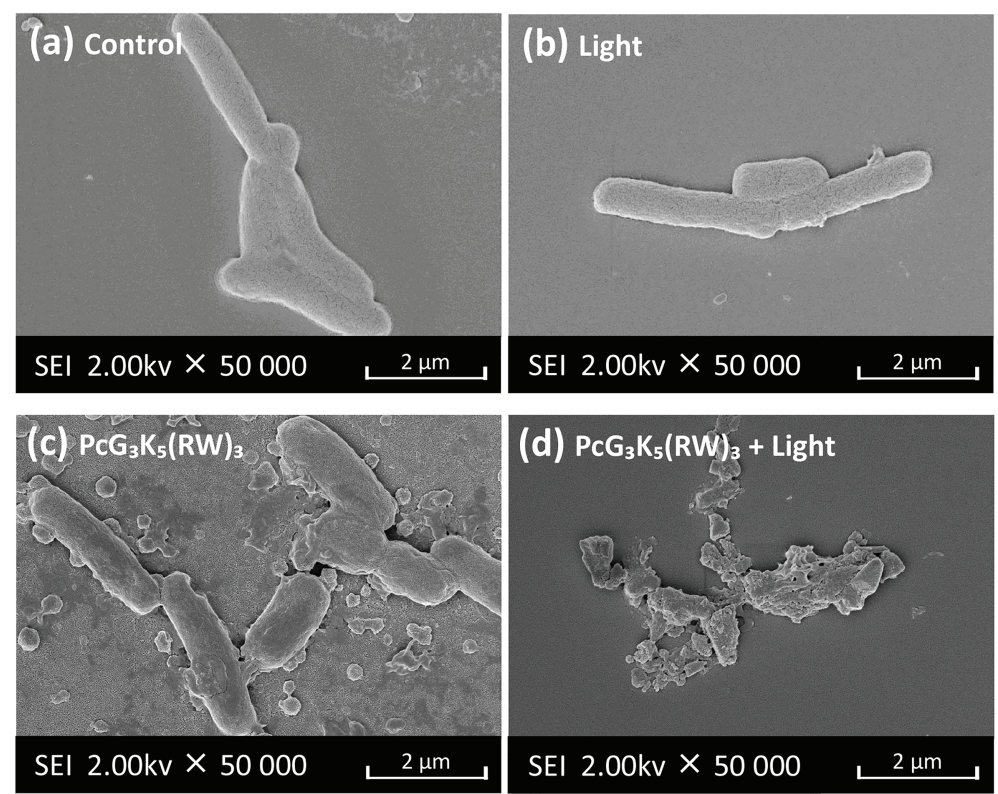

FIGURE 5 | SEM micrographs of E. coli after incubation with $\mathrm{PcG}_{3} \mathrm{~K}_{5}(\mathrm{RW})_{3}\left(23.9 \mu \mathrm{M}\right.$, i.e., IC $\mathrm{C}_{50}$ without light) followed with (A) or without light illumination $\left(6 \mathrm{~J} / \mathrm{cm}{ }^{2}\right.$ $680 \mathrm{~nm})(\mathbf{B})$. E. coli group without incubation with $\mathrm{PcG}_{3} \mathrm{~K}_{5}(\mathrm{RW})_{3}(\mathbf{C})$ and $E$. coli group with light exposure (D) were used as controls. 
A

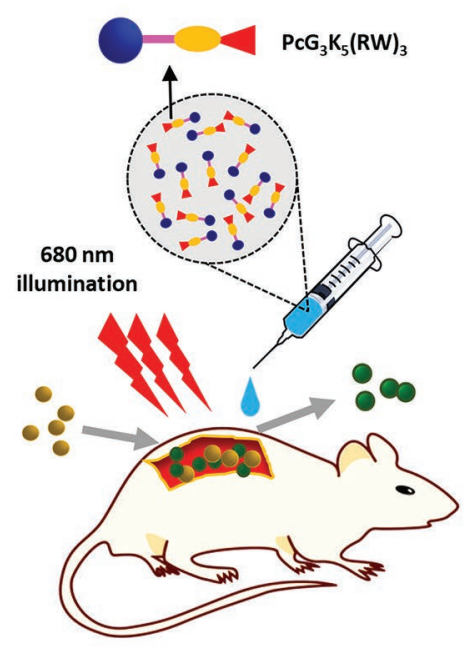

B

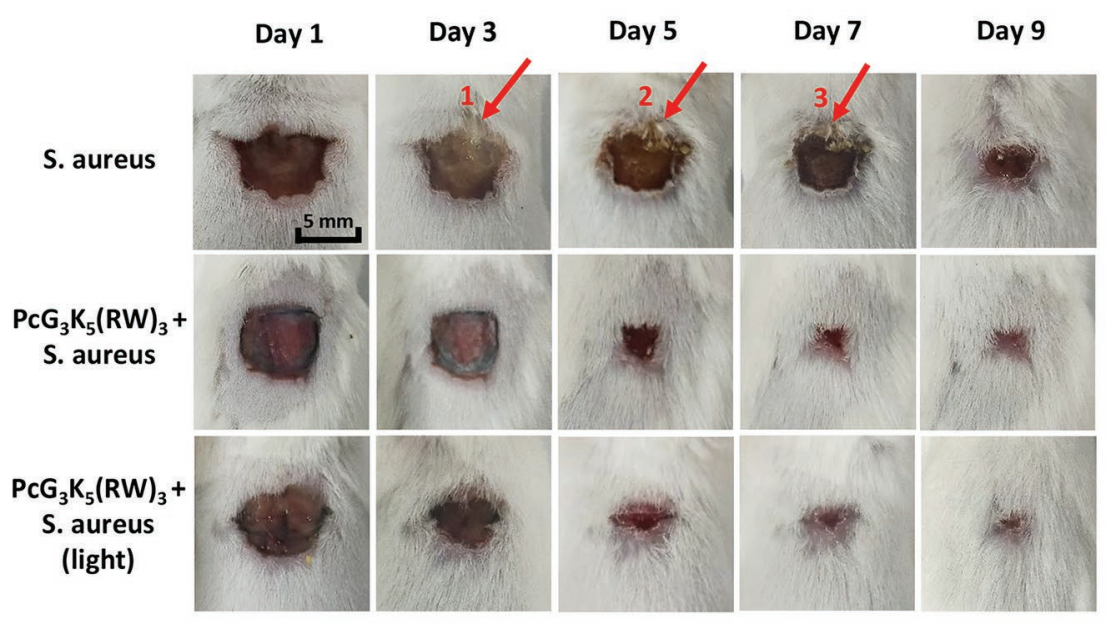

C

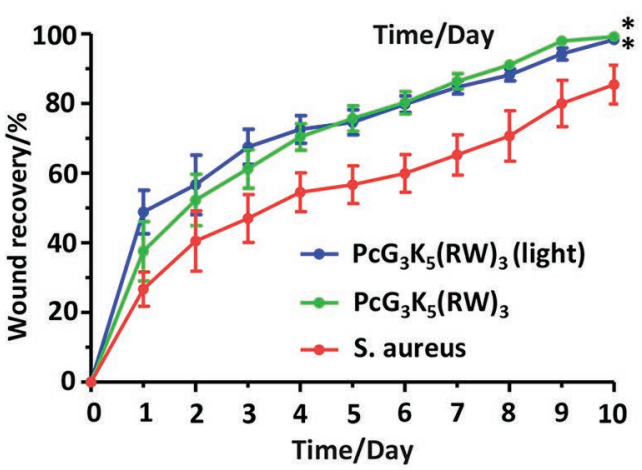

D

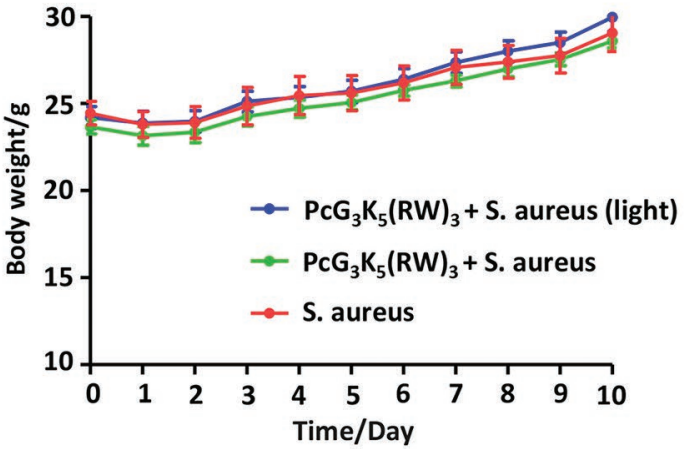

FIGURE 6 | $\mathrm{PcG}_{3} \mathrm{~K}_{5}(\mathrm{RW})_{3}$ promoted wound healing of bacteria-infected wounds. (A) Schematic of animal experiment using PcG $\mathrm{K}_{5}(\mathrm{RW})_{3}$. (B) Images of the wounds in the wound healing model treated in 10 days after surgery. Scale bar: $5 \mathrm{~mm}$ (arrow 1 showed the infected area at wound edge, and arrows 2 and 3 showed the scab formed in infected area). (C) Effects of $\mathrm{PcG}_{3} \mathrm{~K}_{5}(\mathrm{RW})_{3}$ (final concentration of $20 \mu \mathrm{M}$ ) on the healing of $S$. aureus treated excisional wounds in mouse ( $n=6$ per group). (D) The mice gained body weight constantly, demonstrating safety of the antimicrobial peptide. Error bars indicated SD for three replications.

* indicated a significant difference $(p<0.05)$ from the corresponding control group.

antimicrobial compounds showed infection and ulceration at the 3rd day after surgery (Figure 6B). The infection recovered 1-2 days later, and an identifiable scab formed in the infected area. However, the infection did not appear in the groups treated with the local administration of $\mathrm{PcG}_{3} \mathrm{~K}_{5}(\mathrm{RW})_{3}$. This treatment group showed clear healing on the next day after surgery, indicating rapid anti-infection effects of the compound $\mathrm{PcG}_{3} \mathrm{~K}_{5}(\mathrm{RW})_{3}$ on traumatic wound (Figure 6C). The results showed that $\mathrm{PcG}_{3} \mathrm{~K}_{5}(\mathrm{RW})_{3}$ promoted wound healing and prevented or alleviated the infection.

In another group, mice were treated with one-time $680-\mathrm{nm}$ illumination $\left(12.0 \mathrm{~J} / \mathrm{cm}^{2}, 33.33 \mathrm{~mW} / \mathrm{cm}^{2}\right)$ after addition of $\mathrm{PcG}_{3} \mathrm{~K}_{5}(\mathrm{RW})_{3}$ (Supplementary Figure S5). This group showed better wound recovery than the ones without illumination at the first 3 days after surgery. This verified enhanced of illumination on inhibitory efficacy in vitro. Although the light was not essential for $\mathrm{Pc}_{3} \mathrm{~K}_{5}(\mathrm{RW})_{3}$ to promote wound healing in the mammalian infection model, illumination of low-dosage light (below $12 \mathrm{~J} / \mathrm{cm}^{2}, 33.33 \mathrm{~mW} / \mathrm{cm}^{2}$ ) is still an additional method to enhance the efficacy in clinical treatment. Besides, treatment with $\mathrm{PcG}_{3} \mathrm{~K}_{5}(\mathrm{RW})_{3}$ to traumatic wound did not significantly alter the weight gain of mice during the observation (Figure 6D), indicating a good biological compatibility of $\mathrm{PcG}_{3} \mathrm{~K}_{5}(\mathrm{RW})_{3}$.

\section{Biosafety and Stability of $\mathrm{PcG}_{3} \mathrm{~K}_{5}(\mathrm{RW})_{3}$ in vivo}

There are two active components of $\mathrm{PcG}_{3} \mathrm{~K}_{5}(\mathrm{RW})_{3}$ : $\mathrm{Pc}$ and synthetic peptide $\mathrm{G}_{3} \mathrm{~K}_{5}(\mathrm{RW})_{3}$ moiety. Pc-type compounds appear to be safe, as they have been used in close association with human. Pc has been used as a color dye for outfits and underwear in fabric industry for decades. A Pc derivative (Photosense ${ }^{\circledR}$ ) has been used as an antitumor drug for cancer treatment in Ukraine since 1990s. In China, a Pc-based compound (Photocyanine ${ }^{\circledR}$ ) is currently in Phase II clinical trial for patients with esophagus cancer with a dose of 
A

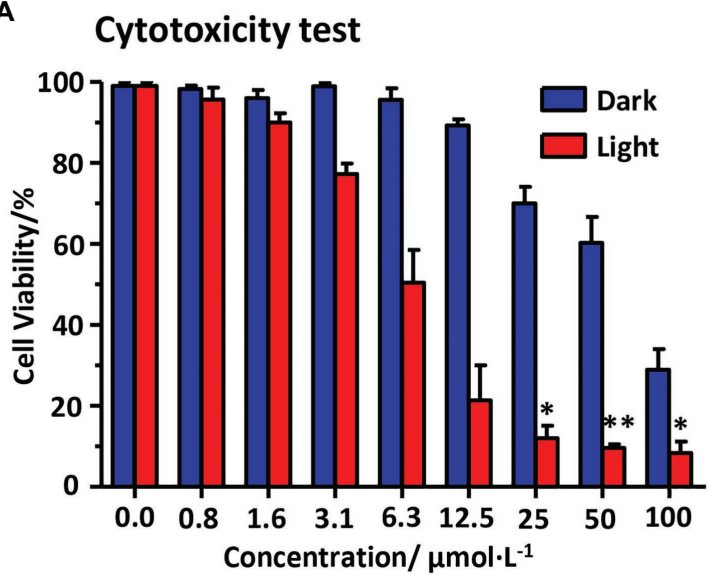

B

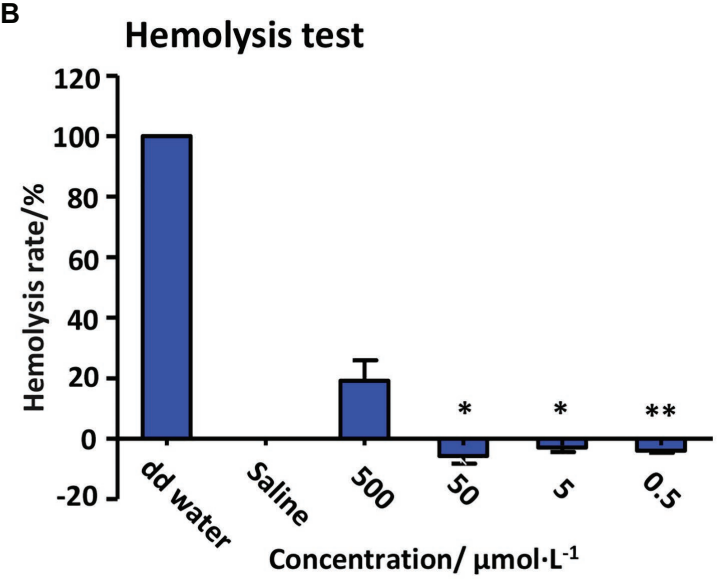

FIGURE 7 | Biosafety of $\mathrm{PCG}_{3} \mathrm{~K}_{5}(\mathrm{RW})_{3}$ in vivo to human embryonic lung fibroblast (HELF) cells (A) with or without light illumination (12 $\mathrm{J} / \mathrm{cm}^{2}, 33.33$ mW/cm²) and to the red blood cells (B). Pure water was used as a control. Error bars indicated SD for three replications. * and ${ }^{* *}$ indicated significant differences $(p<0.05$ and $p<0.01$, respectively) from the corresponding control group.

0.05-0.1 mg/kg (Shao et al., 2012). Its Phase I trial demonstrated no major adverse effect in human at a dose of $2 \mathrm{mg} / \mathrm{kg}$. Pc green (CAS Reg. No. 1328-53-6) has been approved by the FDA to use in contact lens, surgical suture, and latex condom as a color additive.

Despite these apparent safety records of $\mathrm{Pc}$, we still evaluated the biosafety of $\mathrm{PcG}_{3} \mathrm{~K}_{5}(\mathrm{RW})_{3}$ experimentally. We first used the human embryonic lung fibroblast (HELF) cells and red blood cells of mice to evaluate biosafety in vitro. The cells were incubated with $\mathrm{PcG}_{3} \mathrm{~K}_{5}(\mathrm{RW})_{3}$ for $24 \mathrm{~h}$, and the viability was measured by MTT assay (Figure 7A). The result showed that over $90 \%$ of cells survived after incubation with the medium concentration $\left(\mathrm{IC}_{50}\right.$ concentration against $S$. aureus in the absence of light illumination) of $\mathrm{PcG}_{3} \mathrm{~K}_{5}(\mathrm{RW})_{3}$. Under illumination of $12 \mathrm{~J} / \mathrm{cm}^{2}$, the peptide killed only $5 \%$ of HELF cells at the concentration of $0.8 \mu \mathrm{M}$ while inhibiting more than $99.9 \%$ of S. aureus or $99 \%$ of $E$. coli, demonstrating low cytotoxicity to normal mammalian cells. In addition, $\mathrm{PcG}_{3} \mathrm{~K}_{5}(\mathrm{RW})_{3}$ exhibited no cytotoxicity to red blood cells at concentrations of $50 \mu \mathrm{M}$ (Figure 7B), while $\mathrm{IC}_{50} \mathrm{~s}$ of peptide against bacterial strains are below $25 \mu \mathrm{M}$.

Biodistribution and clearance of $\mathrm{PcG}_{3} \mathrm{~K}_{5}(\mathrm{RW})_{3}$ in organs/ tissues were also studied in mice. As shown in Figure $\mathbf{8 A}$, $\mathrm{PcG}_{3} \mathrm{~K}_{5}(\mathrm{RW})_{3}$ accumulated mainly in livers and kidneys but much less in other organs/tissues. The average concentrations of $\mathrm{PcG}_{3} \mathrm{~K}_{5}(\mathrm{RW})_{3}$ in the livers and kidneys reached $\sim 35 \mathrm{nM}$ and $\sim 12 \mathrm{nM}$ at $2-4 \mathrm{~h}$ (Figure $8 \mathrm{~B}$ ) and reduced gradually with time. At $72 \mathrm{~h}$ post-injection, the peptide average concentrations in primary organs/tissues were reduced to low levels $(2-3 \mathrm{nM}$ in livers and kidneys and lower than $1 \mathrm{nM}$ in other organs/tissues). The results showed that $\mathrm{PcG}_{3} \mathrm{~K}_{5}(\mathrm{RW})_{3}$ are mainly accumulated in liver and lung and cleared out in $72 \mathrm{~h}$. Monitoring the Pc fluorescence intensity of compound 4 in mouse blood circulation at different time points after intravenous injection showed the plasma half-life of compound 4 was 11.09 h (Figure 8C).

\section{DATA AVAILABILITY STATEMENT}

The raw data supporting the conclusions of this article will be made available by the authors, without undue reservation.

\section{ETHICS STATEMENT}

The animal study was reviewed and approved by Institutional Animal Care and Use Committee.

\section{AUTHOR CONTRIBUTIONS}

$\mathrm{MH}$ designed the project. $\mathrm{CY}$ and $\mathrm{MH}$ led the project and finalized the manuscript. DZ and QJ carried out the experiments, analyzed the results, and wrote the draft. JC, ZC, AU, LJ, and $\mathrm{KZ}$ assisted in the experiments and result analysis. All authors contributed to the article and approved the submitted version.

\section{FUNDING}

Our research work is financially supported by grants from the National Key R\&D Program of China (2017YFE0103200) and the National Natural Science Foundation of China (22077016, 31670739, and 82070142).

\section{SUPPLEMENTARY MATERIAL}

The Supplementary Material for this article can be found online at: https://www.frontiersin.org/articles/10.3389/fmicb.2021.624465/ full\#supplementary-material 


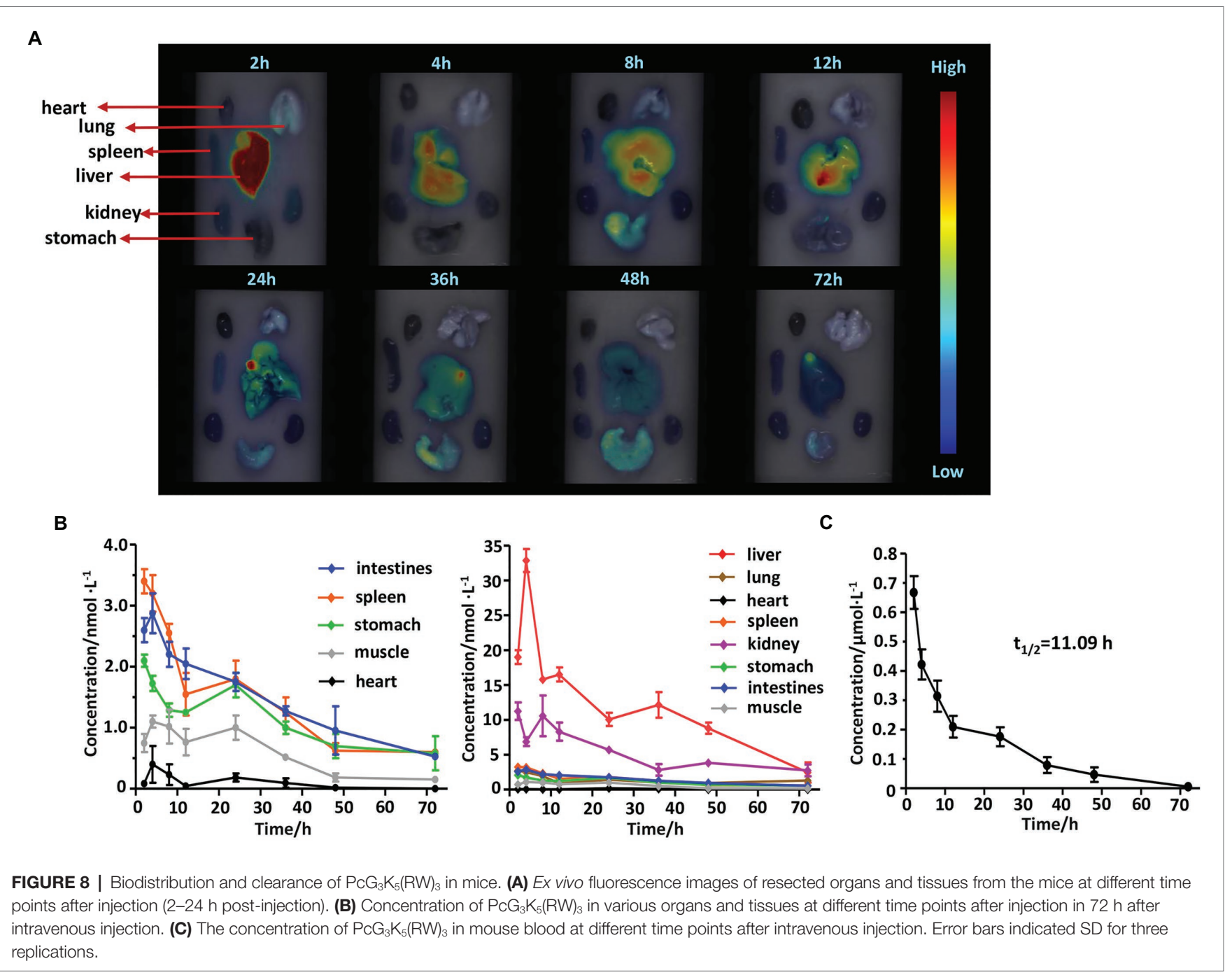

\section{REFERENCES}

Albada, H. B., Chiriac, A. I., Wenzel, M., Penkova, M., Bandow, J. E., Sahl, H. G., et al. (2012). Modulating the activity of short arginine-tryptophan containing antibacterial peptides with $\mathrm{N}$-terminal metallocenoyl groups. Beilstein J. Org. Chem. 8, 1753-1764. doi: 10.3762/bjoc.8.200

Ali-Adib, Z., Clarkson, G. J., McKeown, N. B., Treacher, K. E., Gleeson, H. F., and Stennett, A. S. (1998). Molecular assemblies of novel amphiphilic phthalocyanines: an investigation irate the self-ordering properties of complex functional materials. J. Mater. Chem. 8, 2371-2378. doi: 10.1039/a805557b

Arias, M., Nguyen, L. T., Kuczynski, A. M., Lejon, T., and Vogel, H. J. (2014). Position-dependent influence of the three TRP residues on the membrane activity of the antimicrobial peptide, tritrpticin. Antibiotics 3, 595-616. doi: 10.3390/antibiotics3040595

Bian, Y. Z., and Jiang, J. Z. (2016). Recent advances in phthalocyanine-based functional molecular materials. Struct. Bond. 172, 159-199. doi: 10.1007/430_2015_194

Chen, J. C., Chen, N. S., Huang, J. F., Wang, J. D., and Huang, M. D. (2006). Derivatizable phthalocyanine with single carboxyl group: synthesis and purification. Inorg. Chem. Commun. 9, 313-315. doi: 10.1016/j. inoche.2005.12.002

Chen, J. C., Chen, Z., Zheng, Y. Q., Zhou, S. Y., Wang, J. D., Chen, N. S., et al. (2011). Substituted zinc phthalocyanine as an antimicrobial photosensitizer for periodontitis treatment. J. Porphyrins Phthalocyanines 15, 293-299. doi: $10.1142 /$ S1088424611003276
Chen, J. C., Wang, W. J., Hu, P., Wang, D., Lin, F., Xue, J. P., et al. (2017). Dual antimicrobial actions on modified fabric leads to inactivation of drugresistant bacteria. Dyes Pigments 140, 236-243. doi: 10.1016/j.dyepig.2017.01.032

Chen, J. Y., Yang, L., Chen, J. C., Liu, W. Z., Zhang, D., Xu, P., et al. (2019). Composite of silver nanoparticles and photosensitizer leads to mutual enhancement of antimicrobial efficacy and promotes wound healing. Chem. Eng. J. 374, 1373-1381. doi: 10.1016/j.cej.2019.05.184

Choi, J., and Moon, E. (2009). Identification of novel bioactive hexapeptides against phytopathogenic bacteria through rapid screening of a synthetic combinatorial library. J. Microbiol. Biotechnol. 19, 792-802. doi: 10.4014/ jmb.0809.497

Dennison, S. R., Harris, F., Bhatt, T., Singh, J., and Phoenix, D. A. (2009) The effect of C-terminal amidation on the efficacy and selectivity of antimicrobial and anticancer peptides. Mol. Cell. Biochem. 332, 43-50. doi: 10.1007/s11010-009-0172-8

Gardberg, A. S., Doan, P. E., Hoffman, B. M., and Ibers, J. A. (2001). Singly and doubly oxidized phthalocyanine $(\mathrm{pc})$ rings: $[\mathrm{cu}(\mathrm{pc})(\mathrm{ReO} 4)]$ and $[\mathrm{cu}(\mathrm{pc})$ (ReO4)(2)]. Angew. Chem. 40, 244-246. doi: 10.1002/1521-3773(20010105) 40:1<244::AID-ANIE244>3.0.CO;2-G

Habets, M. G. J. L., and Brockhurst, M. A. (2012). Therapeutic antimicrobial peptides may compromise natural immunity. Biol. Lett. 8, 416-418. doi 10.1098/rsbl.2011.1203

Imai, Y., Meyer, K. J., Iinishi, A., Favre-Godal, Q., Green, R., Manuse, S., et al. (2019). A new antibiotic selectively kills gram-negative pathogens. Nature 576, 459-464. doi: 10.1038/s41586-019-1791-1 
Joshi, U. M., Kodavanti, P. R. S., Coudert, B., Dwyer, T. M., and Mehendale, H. M. (1988). Types of interaction of amphiphilic drugs with phospholipid-vesicles. J. Pharmacol. Exp. Ther. 246, 150-157.

Lewis, K. (2013). Platforms for antibiotic discovery. Nat. Rev. Drug Discov. 12, 371-387. doi: 10.1038/nrd3975

Liu, Z. G., Brady, A., Young, A., Rasimick, B., Chen, K., Zhou, C. H., et al. (2007). Length effects in antimicrobial peptides of the (RW)(n) series. Antimicrob. Agents Chemother. 51, 597-603. doi: 10.1128/AAC. 00828-06

Liu, D. F., Li, L. S., Chen, J. C., Chen, Z., Jiang, L. G., Yuan, C., et al. (2018). Dissociation of zinc phthalocyanine aggregation on bacterial surface is key for photodynamic antimicrobial effect. J. Porphyrins Phthalocyanines 22, 925-934. doi: 10.1142/S1088424618500888

Mahlapuu, M., Hakansson, J., Ringstad, L., and Bjorn, C. (2016). Antimicrobial peptides: an emerging category of therapeutic agents. Front. Cell. Infect. Microbiol. 6:194. doi: 10.3389/fcimb.2016.00194

Misra, R., Morrison, K. D., Cho, H. J., and Khuu, T. (2015). Importance of real-time assays to distinguish multidrug efflux pump-inhibiting and outer membrane-destabilizing activities in Escherichia coli. J. Bacteriol. 197, 2479-2488. doi: 10.1128/JB.02456-14

Morley, J. O., and Charlton, M. H. (1995). Theoretical investigation of the structure and spectra of zinc phthalocyanines. J. Phys. Chem. 99, 1928-1934. doi: $10.1021 / \mathrm{j} 100007 \mathrm{a} 023$

Niu, Y. H., Wu, H. F., Li, Y. Q., Hu, Y. G., Padhee, S., Li, Q., et al. (2013). AApeptides as a new class of antimicrobial agents. Org. Biomol. Chem. 11, 4283-4290. doi: 10.1039/c3ob40444g

Okorochenkov, S. A., Zheltukhina, G. A., and Nebol'sin, V. E. (2012). Antimicrobial peptides: mode of action and perspectives of practical application. Biomed. Khim. 58, 131-143. doi: 10.18097/pbmc20125802131

Payne, D. J., Gwynn, M. N., Holmes, D. J., and Pompliano, D. L. (2007). Drugs for bad bugs: confronting the challenges of antibacterial discovery. Nat. Rev. Drug Discov. 6, 29-40. doi: 10.1038/nrd2201

Radzishevsky, I. S., Rotem, S., Bourdetsky, D., Navon-Venezia, S., Carmeli, Y., and Mor, A. (2007). Improved antimicrobial peptides based on acyl-lysine oligomers. Nat. Biotechnol. 25, 657-659. doi: 10.1038/nbt1309

Radzishevsky, I. S., Rotem, S., Zaknoon, F., Gaidukov, L., Dagan, A., and Mor, A. (2005). Effects of acyl versus aminoacyl conjugation on the properties of antimicrobial peptides. Antimicrob. Agents Chemother. 49, 2412-2420. doi: 10.1128/AAC.49.6.2412-2420.2005

Sauermann, R., Rothenburger, M., Graninger, W., and Joukhadar, C. (2008). Daptomycin: a review 4 years after first approval. Pharmacology 81, 79-91. doi: 10.1159/000109868

Shao, J., Xue, J., Dai, Y., Liu, H., Chen, N., Jia, L., et al. (2012). Inhibition of human hepatocellular carcinoma HepG2 by phthalocyanine photosensitiser PHOTOCYANINE: ROS production, apoptosis, cell cycle arrest. Eur. J. Cancer 48, 2086-2096. doi: 10.1016/j.ejca.2011.10.013

Smith, P. A., Koehler, M. F. T., Girgis, H. S., Yan, D. H., Chen, Y. S., Chen, Y., et al. (2018). Optimized arylomycins are a new class of gram-negative antibiotics. Nature 561, 189-194. doi: 10.1038/s41586-0180483-6
Strom, M. B., Haug, B. E., Skar, M. L., Stensen, W., Stiberg, T., and Svendsen, J. S. (2003). The pharmacophore of short cationic antibacterial peptides. J. Med. Chem. 46, 1567-1570. doi: 10.1021/jm0340039

Strom, M. B., Rekdal, O., and Svendsen, J. S. (2002). Antimicrobial activity of short arginine- and tryptophan-rich peptides. J. Pept. Sci. 8, 431-437. doi: $10.1002 /$ psc.398

Tacconelli, E., Carrara, E., Savoldi, A., Harbarth, S., Mendelson, M., Monnet, D. L., et al. (2018). Discovery, research, and development of new antibiotics: the WHO priority list of antibiotic-resistant bacteria and tuberculosis. Lancet Infect. Dis. 18, 318-327. doi: 10.1016/S1473-3099(17)30753-3

Ullah, A., Zhang, Y. X., Iqbal, Z., Zhang, Y. X., Wang, D., Chen, J. C., et al. (2018). Household light source for potent photodynamic antimicrobial effect and wound healing in an infective animal model. Biomed. Opt. Express 9, 1006-1019. doi: 10.1364/BOE.9.001006

Wainwright, M., Maisch, T., Nonell, S., Plaetzer, K., Almeida, A., Tegos, G. P., et al. (2017). Photoantimicrobials-are we afraid of the light? Lancet Infect. Dis. 17, E49-E55. doi: 10.1016/S1473-3099(16)30268-7

Wenzel, M., Chiriac, A. I., Otto, A., Zweytick, D., May, C., Schumacher, C., et al. (2014). Small cationic antimicrobial peptides delocalize peripheral membrane proteins. Proc. Natl. Acad. Sci. U. S. A. 111, E1409-E1418. doi: 10.1073/pnas.1319900111

Wenzel, M., Prochnow, P., Mowbray, C., Vuong, C., Hoxtermann, S., Stepanek, J. J., et al. (2016a). Towards profiles of resistance development and toxicity for the small cationic hexapeptide RWRWRW-NH2. Front. Cell Dev. Biol. 4:86. doi: $10.3389 /$ fcell.2016.00086

Wenzel, M., Schriek, P., Prochnow, P., Albada, H. B., Metzler-Nolte, N., and Bandow, J. E. (2016b). Influence of lipidation on the mode of action of a small RW-rich antimicrobial peptide. Biochim. Biophys. Acta Biomembr. 1858, 1004-1011. doi: 10.1016/j.bbamem.2015.11.009

Wrobel, D., and Dudkowiak, A. (2006). Porphyrins and phthalocyaninesfunctional molecular materials for optoelectronics and medicine. Mol. Cryst. Liq. Cryst. 448, 15-38. doi: 10.1080/15421400500377354

Zhang, Y. X., Huang, P., Wang, D., Chen, J. C., Liu, W. Z., Hu, P., et al. (2018). Near-infrared-triggered antibacterial and antifungal photodynamic therapy based on lanthanide-doped upconversion nanoparticles. Nanoscale 10, 15485-15495. doi: 10.1039/C8NR01967C

Zhang, Y. X., Zheng, K., Chen, Z., Chen, J. C., Hu, P., Cai, L. R., et al. (2017). Rapid killing of bacteria by a new type of photosensitizer. Appl. Microbiol. Biotechnol. 101, 4691-4700. doi: 10.1007/s00253-017-8133-8

Conflict of Interest: The authors declare that the research was conducted in the absence of any commercial or financial relationships that could be construed as a potential conflict of interest.

Copyright (c) 2021 Zhang, Chen, Jing, Chen, Ullah, Jiang, Zheng, Yuan and Huang. This is an open-access article distributed under the terms of the Creative Commons Attribution License (CC BY). The use, distribution or reproduction in other forums is permitted, provided the original author(s) and the copyright owner(s) are credited and that the original publication in this journal is cited, in accordance with accepted academic practice. No use, distribution or reproduction is permitted which does not comply with these terms. 